Sandra Stojadinović Jovanović ${ }^{1}$

Academy of Professional Studies Western Serbia

\section{Bojan Krstić ${ }^{2}$}

University of Niš, Faculty of Economics

Milan Marković ${ }^{3}$

University of Niš, Innovation Center
P. 25-36

SCIENTIFIC REVIEW ARTICLE

DOI: $10.5937 / \mathrm{ESD} 2002025 \mathrm{~S}$

Received: Jun, 01. 2020.

Accepted: July, 11. 2020.

\title{
INTERNATIONAL BUSINESS AND MANAGEMENT IN PANDEMIC-RELATED CONDITIONS ${ }^{4}$
}

\begin{abstract}
The aim of the paper is to give the insight into international business and management in pandemic-related conditions in the first half of 2020. The subject of the paper is the analysis of the impact of the initial pandemic wave on the conditions in which international business and management take place and the risks to which companies are exposed, the ways they react to these conditions regarding the business ventures they give up or undertake, as well as the possibilities of how to cope with the current pandemic conditions. Therefore, the paper consists of three parts which analyze each of these aspects. In the pandemic-related conditions, full of unknowns and declining trends of almost all economic indicators, managers have a significant and additional responsibility to consider all relevant aspects and act accordingly making possibilities to mitigate the effects of a pandemic and to get through it.
\end{abstract}

Key words: international business, management, pandemic, COVID-19.

JEL classification: F21, F23

\section{МЕБУНАРОДНО ПОСЛОВАЊЕ И МЕНАЏМЕНТ У УСЛОВИМА ПАНДЕМИЈЕ}

\begin{abstract}
Апстракт
Циљ рада је да ирружи увид у одвијане међународног йослована и менаименйа у условима йандемије у ирвој иоловини 2020. године. Предмеии рада чини анализа уйицаја иницијалног йаласа йандемије на услове у којима се међународно йословаюе и меначменй одвија и ризике којима су изложене

\footnotetext{
${ }^{1}$ sandrassj28@gmail.com, ORCID ID 0000-0003-1383-0225

${ }^{2}$ bojan.krstic@eknfak.ni.ac.rs, ORCID ID 0000-0003-4597-6819

${ }^{3}$ markovicmilan89@gmail.com, ORCID ID 0000-0002-9617-6697

${ }^{4}$ The paper is a part of the research financed by the Ministry of Education, Science and Technological Development of the Republic of Serbia (Agreement on the implementation and financing of scientific research in 2020; registration number 451-03-68/2020-14/200100 and 451-03-68/202014/200371).
} 
комйаније, начине на које реагују на ове услове имајући у виду иоословне йодухвайе од којих одусииају или које иредузимају, као и могућностии како да се носе са йосйојећим условима йандемије. Зайо се рад сасйоји из иири дела, који анализирају сваки од ових асиекайа. У условима йандемије, који обилују нейознанииама и иррендовима ойадана гориово свих економских индикайора, меначери имају значајну и додайну одговорносй да размойре све релеваниине асиекие и йонашају се сходно юима сивварајући могуућносии за ублажаваюе иоследииа йандемије и юено иревазилажене.

Кључне речи: међународно йословане, меначменй, йандемија, COVID-19.

\section{Introduction}

International business can be observed through different forms of doing international business operations, including exports, licenses, franchising, joint ventures, and majority-owned affiliate in a foreign market. The form of international business that has had the greatest expansion in the previous thirty years is the establishment of a majority-owned affiliate through undertaking direct investments abroad (FDI). FDI is a form of international capital movements that are important for almost all countries (Stojadinović Jovanović, 2015). This form of business is the most complex, the most expensive, and the most risky. However, as the possibility of making higher profits comes with higher risks, this form of business has achieved the greatest expansion. Flows and volume of this, the most prominent form of international business operations, can be followed and analyzed through flows and volumes of FDI and their different types, primarily greenfield investments, and cross-border mergers and acquisitions (M\&A).

Management of international business operations on an ordinary basis is generally more complex than management of business operations within national borders. Additionally, changes of business conditions and environment, especially those of recessions and crisis, make it more complex, risky and uncertain.

Current business conditions and international, as well as national environment, are additionally complicated and disturbed by the global epidemic of coronavirus (COVID-19), that is the COVID-19 crisis. It makes a huge impact on the entire world economy and within it on international business and its management.

\section{Current business pandemic-related conditions and risks}

Current business conditions are characterized by numerous unknowns and significant slowdowns. "In general, a new turbulent business environment has created a new scenario for the competitive development of companies in the XXI century" (Janjić, Bogićević \& Krstić, 2019, p. 14). Additionally, the pandemic conditions have made the environment more complex. The current macroeconomic environment is unpropitious and full of unfavourable movement. The economic disruptions triggered by the pandemic are huge and overall. It is expected that many indicators of global activity recorded the highest decline in the past few decades. It is estimated that the crisis caused by COVID-19 
will be the biggest so far, even twice as deep as the last economic and financial crisis from 2007-2008.

Globally, the volume of trade is declining, while gross domestic product tends to slow down. "The World Bank has predicted a decline of world GDP by $5.2 \%$ in 2020 " (WB, 2020, p. 4). It is expected the significant reduction of economic output in almost every country. World trade also fell sharply in the first half of the year. The volume of merchandise trade shrank by $3 \%$ year-on-year in the first quarter (WTO, 2020).

"There are also a 9\% year-on-year fall in global production and manufacturing output, fall in value of global merchandise trade by almost $27 \%$ in the second quarter of 2020 , the largest fall in global commodity process on record $(-20.4 \%$ between February and March 2020), and the shocking loss of employment - a decline of almost $10.5 \%$ in total working hours, the equivalent of 305 million full-time workers" (CCSA, 2020, p. 3) Some economists predict that world unemployment will be the highest since 1965 (Kose \& Sugawara, 2020).

In such conditions there are numerous risks (WEF, 2020b) which the companies are dealing with. Prolonged recession of the global economy is estimated to be the highest COVID-19 risk that companies face. This risk is followed by other economic, as well as societal (another global outbreak of COVID-19 or different infectious disease), technological (cyberattacks and data fraud due to a sustained shift in working patterns, as well as breakdown of IT infrastructure and networks), and geopolitical (tighter restrictions on the cross-border movement of people and goods) risks (Table 1).

Beside prolonged global recession, as a top concern for business, the greatest economic risks in terms of the most worrisome for the companies are bankruptcies and industry consolidation, failure of industries to recover, and a protracted disruption of supply chains. The technological risk of cyberattacks and data fraud is the third one among the most worrisome risks for companies, as well as the related eleventh risk of breakdown of IT infrastructure and networks.

Shift in working patterns includes huge application of technology and increased working from home and other remote locations, and therefore raises risks of cyberattacks and data fraud. With the pandemic increase and acceleration, reliance on technology in both every day and business life, has also increased cyberattacks and data fraud risks. Although technology should have the primary role in mitigating and overcoming the COVID-19 crisis, on the other side the pandemic-related conditions have hightened those risks.

Table 1: Top concerns and risks for companies

\begin{tabular}{|c|l|l|}
\hline 1. & Prolonged recession of the global economy & Economic \\
\hline 2. & Surge in bankruptcies (big firms and SMEs) and & Economic \\
\hline 3. & a wave of industry consolidation & \\
\hline 4. & Failure of industries or sectors in certain countries to properly recover & Economic \\
\hline 5. & Protracted disruption of global supply chains & Economic \\
\hline 6. & Tighter restrictions on the cross-border movement of people and goods & Geopolitical \\
\hline 7. & Another global outbreak of COVID-19 or different infectious disease & Societal \\
\hline
\end{tabular}




\begin{tabular}{|c|l|l|}
\hline 8. & Economic collapse of an emerging market or developing economy & Economic \\
\hline 9. & Weakening of fiscal positions in major economies & Economic \\
\hline 10. & Sharp increase in inflation globally & Economic \\
\hline 11. & Breakdown of IT infrastructure and networks & Tech \\
\hline 12. & High levels of structural unemployment (especially youth) & Economic \\
\hline 13. & Massive capital outflows and slowdown in foreign direct investment & Economic \\
\hline 14. & Exacerbation of mental health issues & Economic \\
\hline 15. & Sharp underfunding of retirement due to pension fund devaluation & Economic \\
\hline
\end{tabular}

Source: WEF (2020a). COVID-19 Risks Outlook: A Preliminary Mapping and Its Implications. Geneva. p. 53.

In the first week of April, it can be seen a huge increase in the number of attacks, to an average of 14,000 a day, which is six times the average number of daily attacks when compared to the previous two weeks (Figure 1). And over the second week in April, the average number of daily attacks increased sharply to 20,000 (Check Point Software Technologies, 2020).

Figure 1: Coronavirus-related cyberattacks detected worldwide,

December $31^{\text {st }}, 2019$ to April $14^{\text {th }}, 2020$

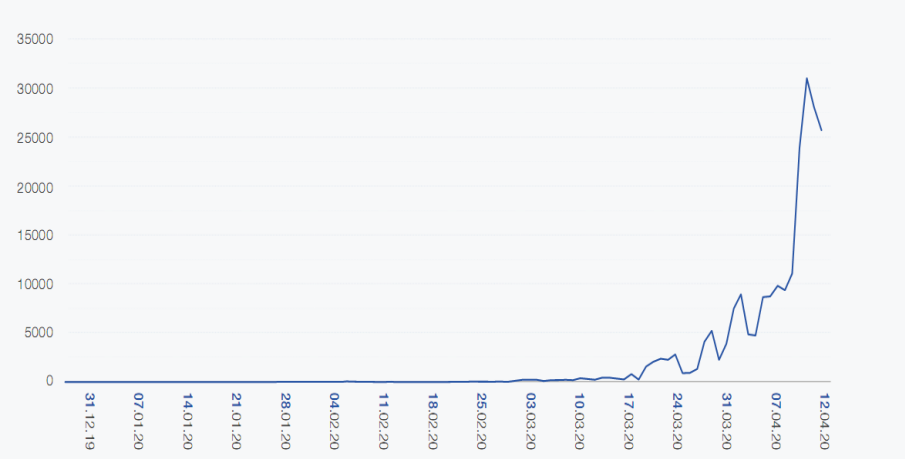

Source: Check Point Software Technologies. (2020). Coronavirus update: as economic stimulus payments start to flow; cyber-attackers want to get their share too. Retrieved July 24, 2020, from https://blog.checkpoint.com/2020/04/20/coronavirus-update-as-economicstimulus-payments-start-to-flow-cyber-attackers-want-to-get-their-share-too/

The fifth most worrisome aspect for companies is protracted disruption of global supply chains, which have affected companies around the world. The lockdowns and halts in production caused by pandemic in leading economies of China, the European Union and the United States, have had great impacts on production, imports and exports, and reduced the inputs available for global supply chains. Many companies around the world, which supply affected countries, have experienced a decline in orders as demand has fallen.

Among the top ten concerns for companies, there are only one geopolitical and one societal risk. Companies are mostly concerned about the geopolitical risk of disruptions to 
business assessing tighter restrictions on the movement of people and goods. Companies are also concerned about societal risk regarding another global outbreak of COVID-19 or other infectious disease.

The coronavirus pandemic could also trigger permanent changes in consumer behavior, which would pose new challenges to businesses. Following the financial crisis, global consumption grew at the slowest pace for any 10-year period on record (WB Open Data, 2020), which is a downward trend that is likely to continue in the current conditions. Businesses can easily face reputational costs and consumer rejection, depending on how they behave in this crisis, especially in relation to employment (WEF, 2020a).

\section{Companies' response to the pandemic}

At the beginning of the pandemic, companies around the world responded in similar ways. They informed customers whether the business would be suspended and accordingly took measures to protect employees and customers from infection. Furthermore, many companies have sought support from business support organizations, government, and other supporting entities. However, beyond this common reaction, there were differences between companies in response. Some adopted retreating strategies, many were resilient, while some were notably agile.

Many companies reduced employment, sold assets, or took on new debt to cope with COVID-19 crisis. "It can be observed that small export companies were significantly less likely to adopt this kind of approach than those selling only to the domestic market" (ITC, 2020, p. 38).

The most common practice that companies have resorted to was temporary reduction in employment. Furthermore, smaller companies increased online sales, while medium and large companies increased teleworking as they are generally more capable of working from home than smaller companies (Table 2).

In pandemic-related conditions, international business operations have been reduced. This is reflected in the FDI data, and their main types, greenfield investments, and cross-border mergers and acquisitions.

The pandemic conditions have had immediate effects on international business due to reduced FDI by companies. It is predicted that the pandemic conditions will cause a dramatic drop in FDI in 2020, with a further deterioration in 2021. "It is estimated that global FDI flows will decrease in 2020 by up to $40 \%$ from their 2019 value, resulting in FDI below $\$ 1$ trillion for the first time since 2005. FDI is further expected to decline by $5 \%$ to $10 \%$ in $2021 "$ (UNCTAD, 2020, pp. 2-3).

Companies have reduced their international business operations all over the world across all groups of countries. "According to UNCTAD projections, developed economies will realize negative annual FDI growth rate in 2020 of between $-25 \%$ and $-40 \%$, while developing and transition economies will achieve larger decline of between $-30 \%$ and -45\%" (UNCTAD, 2020, pp. 8-9). 
Table 2: The ways in which companies cope with pandemic

\begin{tabular}{|c|c|c|c|c|c|c|c|}
\hline \multicolumn{2}{|c|}{ Micro companies } & \multicolumn{2}{|c|}{ Small companies } & \multicolumn{2}{c|}{ Medium companies } & \multicolumn{2}{c|}{ Large companies } \\
\hline $\begin{array}{c}\text { Temporarily reduced } \\
\text { employment }\end{array}$ & $34 \%$ & $\begin{array}{c}\text { Temporarily } \\
\text { reduced } \\
\text { employment }\end{array}$ & $42 \%$ & $\begin{array}{c}\text { Temporarily } \\
\text { reduced } \\
\text { employment }\end{array}$ & $40 \%$ & Teleworking & $58 \%$ \\
\hline Online sales & $31 \%$ & Online sales & $25 \%$ & Teleworking & $38 \%$ & $\begin{array}{c}\text { Temporarily } \\
\text { reduced } \\
\text { employment }\end{array}$ & $42 \%$ \\
\hline $\begin{array}{c}\text { Customized/new } \\
\text { products }\end{array}$ & $20 \%$ & Teleworking & $25 \%$ & $\begin{array}{c}\text { Increased } \\
\text { marketing efforts }\end{array}$ & $26 \%$ & $\begin{array}{c}\text { Increased } \\
\text { marketing efforts }\end{array}$ & $26 \%$ \\
\hline
\end{tabular}

Source: ITC (2020). SME Competitiveness Outlook 2020: COVID-19: The Great Lockdown and its Impact on Small Business. Geneva. p. 40.

Companies have also reduced their international business operations across all industries. The average growth rate of number of announced greenfield projects, as well as the average growth rate of number of announced cross-border mergers and acquisitions deals has been negative in all sectors: primary, manufacturing, and services. In the first months of 2020, all industries experienced an average decline of more than $20 \%$ in the number of newly announced greenfield projects. The same situation is with the number of newly announced cross-border M\&A deals, except in primary sector where the average decline was $9 \%$ (Table 3).

Table 3: Pandemic impact on FDI projects, early 2020 (in percent)

\begin{tabular}{|l|c|c|}
\hline \multirow{2}{*}{ Industry } & \multicolumn{2}{|c|}{ Number of project/deals growth rate, monthly average Q1 2020 vs all 2019 } \\
\cline { 2 - 3 } & Greenfield projects & Cross-border M\&A deals \\
\hline Primary & -29 & -9 \\
\hline Manufacturing & -38 & -22 \\
\hline Services & -23 & -21 \\
\hline Total & -30 & -21 \\
\hline
\end{tabular}

Source: UNCTAD (2020). World Investment Report 2020. New York and Geneva, p. 6.

Companies have cancelled a significant number of announced greenfield projects and cross-border mergers and acquisitions deals in the first months of 2020 compared to 2019. The numbers of announced greenfield projects in March and cross-border mergers and acquisitions deals in April decreased by over 50\% compared to the 2019 monthly average (Figure 2).

Some companies that have cancelled M\&A deals in the period February-April 2020 for pandemic-related reasons are:

- Alimentation Couche-Tard (Canada), which withdrew its plans to acquire the share capital of petrol station operator Caltex Australia for an estimated \$5.6 billion (Reuters, 2020);

- $\quad$ Public Storage (United States), which withdrew its plans to acquire the share capital of National Storage REIT, an Australia-based publicly-traded REIT, for an estimated $\$ 1.2$ billion (Business Wire, 2020a);

- Asia Pacific Village Group, an entity owned by the EQT Infrastructure IV, 
which terminated its Scheme Implementation Agreement with Metlifecare (New Zealand) in a \$1 billion deal (Company News HQ, 2020);

- "HOT Telecommunication Systems, a subsidiary of NextAlt SARL (Luxembourg), which withdrew its tender offer for the share capital of Partner Communications (Israel) for $\$ 900$ million" (UNCTAD, 2020, p. 4);

- Melco Resorts \& Entertainment (Hong Kong, China), which announced that it would drop investment plans in Crown Resorts (Australia) in a transaction worth $\$ 600$ million (Ggrasia, 2020);

- Alphatec Holdings (United States), which terminated its tender offer for a stake in EOS Imaging (France) for about \$100 million (Business Wire, 2020b).

Figure 2: Announced greenfield projects and cross-border mergers and acquisitions deals, monthly and average number, 2019 and early 2020

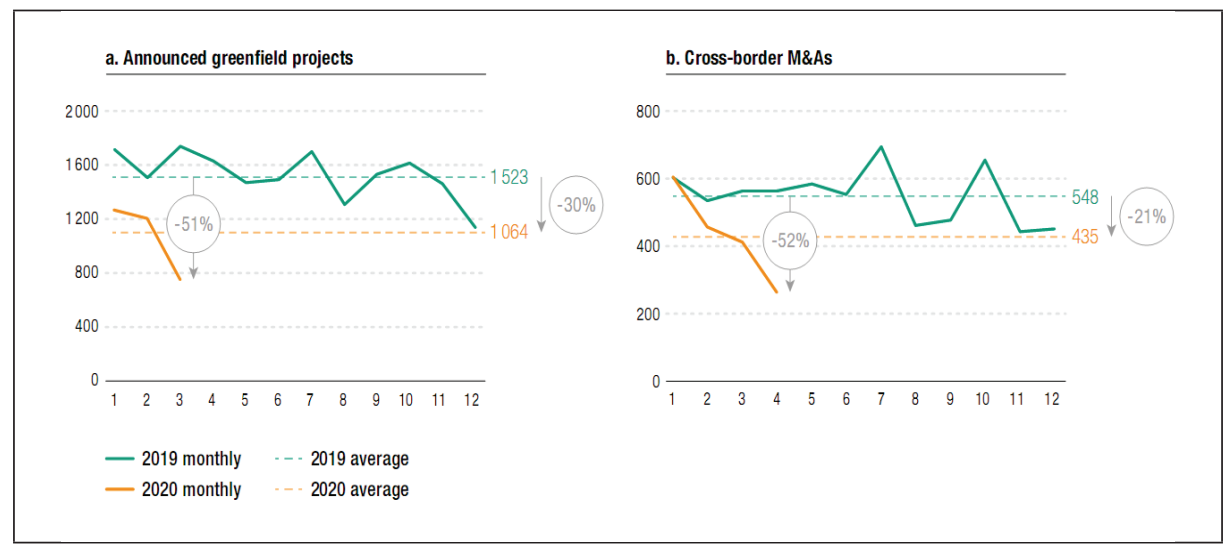

Source: UNCTAD (2020). World Investment Report 2020. New York and Geneva, p. 5.

Some companies have play significant role in tackling and fighting the pandemic and limiting disruptions to economies. Many of them are leaders in their industries. For example:

- PwC, inter alia, has created a free COVID-19 Navigator, a digital assessment to help organizations understand the impact of COVID-19 on their business and assess their readiness to respond. $\mathrm{PwC}$ works with the government to help the corporate sector. "Along with financial donations to charities, $\mathrm{PwC}$ has donated medical supplies and equipment to hospitals and medical centers" (Clift \& Court, 2020);

- Koç Holding, Turkey's largest investment holding company, has mobilized its capital to reduce the risk of coronavirus. Arçelik, a Koç Holding subsidiary and leading consumer durables manufacturer in Europe, is undertaking the mass production of life-saving mechanical ventilators to help the country avoid possible shortages (Clift \& Court, 2020);

- two of the world's biggest vaccine makers, GlaxoSmithKline (GSK) and Sanofi, are collaborating on a COVID-19 vaccine (Clift \& Court, 2020);

- $\quad$ PepsiCo is directing \$45 million COVID-19 response initiative to communities hardest hit by the pandemic (Clift \& Court, 2020); 
- $\quad$ LEGO will donate US \$50 million to ensure children, particularly those most affected by the COVID-19 crisis, continue to have access to learning through play (Clift \& Court, 2020);

- $\quad$ H\&M has offered to donate and source supplies of protective masks, gowns and gloves to countries most affected in the EU. "Luxury firm LVMH, which owns Louis Vuitton, Bulgari, TAG Heuer and many other brands, will use its perfume production infrastructure to make hand sanitize" (Clift \& Court, 2020).

\section{Possibilities to mitigate the effects of a pandemic}

To survive and compete successfully in an increasingly demanding market, "companies must use best management practices, strategies and tools" (Janjić, Bogićević \& Krstić, 2019, p. 14). In pandemic conditions all these requirements become even more complex. The business was not prepared for the pandemic conditions and COVID-19 crisis. Although, this does not mean business should not make possibilities to mitigate the effects of a pandemic and get through it, and also make a preparation for the next no matter what form would it take (pandemic, extreme weather, fires, etc.). There are several aspects standing out in this current matter regarding international business and its management.

The important question is what international business strategies should include: retreat, resilience and/or agility (ITC, 2020), that is, what kind of a strategy to adopt to deal with the pandemic.

The first one, retreat, although undermine the competitiveness of companies, implies that companies are forced to exercise caution and withdraw from circumstances that cannot change. However, retreat measures often involve doing nothing or taking emergency measures that will cause damage in the long run.

The second one, resilience, includes an adaptive approach to the business and environmental circumstances. In the current context of pandemic-related conditions, resilience may include shifting the sales mix towards online channels, sourcing from new suppliers or learning to telework (ITC, 2020).

Resilience of different business aspects is very important in current pandemic conditions, including leadership, revenue, organizational, financial and operational component of resilience (Isenberg et al., 2020) in the following way:

- Leadership resilience should imply strengthening the entire network of relationships, including all stakeholders, from customers and suppliers to the community. In the context of a global epidemic, this aspect additionally gained in importance;

- Revenue resilience should imply nurturing long-term relationships with customers. In pandemic conditions that could be, for example, by upgrading sales management through moving it towards the cloud to facilitate remote access and spread the risk of a specific location losing connectivity;

- Organizational resilience should imply resolving organizational issues differences, more detailed, and precise. In pandemic conditions, it should include, for example, the establishment of clear written guidelines for who 
makes what decisions, the systematization of the free and fearless flow of information from employees, the creation a written plan for cost-cutting in the event of a shift, the communication of bad news clearly, concisely and with empathy, updated daily, with realism, transparency and honesty, the announcement of cutbacks or staff changes to the entire company and the creation a forum for discussion;

- Financial resilience should imply to have a firm grasp on how money moves through the company, especially in pandemic conditions. Furthermore, to negotiate cancellation or service suspension clauses into all future supply contracts, to negotiate credit facilities with bankers and credit lines with suppliers, to introduce new payment terms and provide discounts for early payments and to demand longer payment deadlines or discounts from suppliers without hesitation;

- Operational resilience means mapping the supply chain from raw materials to the end customer and identifying all vulnerabilities, especially in a pandemic. Moreover, conducting a formal audit of production and service logistics and establishing a written protocol for communication with suppliers during the crisis, implementing a data-security plan for information infrastructure and forming task forces and communications platforms in fixing issues without delay (Isenberg et al, 2020).

Renjen (2020) outlines five fundamental qualities of resilient leadership which should help executives to ensure their companies emerge stronger from the impact of coronavirus, which imply:

- "Design from the heart... and the head", what implies that resilient leaders are sincerely empathetic with their employees, customers and their stakeholders, while at the same time they must maintain rationality in order to protect the financial position of the company;

- $\quad$ "Put the mission first", what implies that resilient leaders are capable in triage, able to stabilize their organizations in times of crisis, while at the same time finding the least bad solutions despite visible limitations;

- "Aim for speed over elegance", what implies that resilient leaders take courageous and decisive action based on incomplete information;

- "Own the narrative", what implies that resilient leaders seize the narrative at the outset. They are transparent about a current situation, while at the same time they provide a convincing picture of the future that inspires others to persevere;

- "Embrace the long view" what implies that resilient leaders are long-run oriented anticipating the new business models and innovations that will shape the future.

It is also important to distinguish three time frames through which a typical crisis plays out. These frames are (Deloitte, 2020, p. 2):

- Respondent, in which a company deals with the present situation and manages continuity;

- $\quad$ Recover, during which a company learns and emerges stronger; and

- Thrive, where the company prepares for and shapes the 'next normal'. 
Managers have a significant and additional responsibility to consider all three frames, to identify where their organization is, and to allocate resources accordingly.

The third one, agility, implies constructive reaction and adaptation to situation and risk, including creation of new products and services and/or business models. Agility during the pandemic conditions may include creation of new products, such as designer masks and rapid testing technologies or business models in which employees are lent to other active businesses in essential industries.

Beyond the previous, another important aspect is the digitalization of business. The pandemic represents an additional impetus for further expansion of business digitalization. New creative solutions can satisfy wide groups of users faster. Updating business models, especially adopting and updating digital business models, is now an imperative for almost every company in order to survive and compete.

Digital transformation is not a new request for business. However, the pandemic will force companies to speed up their digital transformations. Leaders in companies will face many challenges and opportunities. In these conditions, successful leaders will take the opportunity to determine a new path for digital transformation that coincides with the flexible role of business. (George \& Lukhele, 2020).

The important roles in the process of business survival and recovery have business support organizations, including chambers of commerce, sector associations, trade promotion organizations, investment promotion agencies, as well as banks, insurance companies, and other supporting entities. They must continue to deliver their services, although they are facing greater concerns and risks.

Transparency and access to information are also important and critical, especially in order to obtain information about COVID-19-related assistance programs, government initiatives, and other related assistance initiatives.

In the pandemic-related conditions, full of unknowns and declining trends of almost all economic indicators, managers have a huge responsibility to consider everything previously stated and act accordingly. There are beliefs that the COVID-19 crisis may also become an opportunity for companies to create even greater value and positive social impact. (Deloitte Insights, 2020).

\section{Conclusion}

The economic disruptions triggered by the pandemic are huge and overall. There are numerous risks which the companies are dealing with and which affect the reaction of companies. At the beginning of the pandemic, companies responded in similar ways. However, beyond this common reaction, there were differences between companies in response.

The pandemic conditions have had immediate effects on international business operations. Companies have reduced their international business operations all over the world across all groups of countries, and all industries. A significant number of announced greenfield projects and cross-border mergers and acquisitions deals has been cancelled. On the other side, some companies, leaders in their industries, have played a significant role in tackling and fighting the pandemic, and limiting disruptions to economies. 
The far-reaching impact of COVID-19 has unquestionably put the new focus on how companies respond, and how they should respond to this kind of crisis. The pandemic crisis will certainly start new forms of business and with the change of business behavior on a global level.

In this kind of crisis, pandemic-related, full of unknowns and declining trends of almost all economic indicators, managers have a significant and additional responsibility to consider all relevant aspects and act accordingly making possibilities to mitigate the effects of a pandemic and to get through it. The current situation may be seen as a form of test of the ability of all kinds of businesses and managers to cope with this type of crisis. The pandemic conditions will shed light on which strategies will allow businesses and economies to survive and recover.

\section{References}

Business Wire. (2020a). Public Storage Reports Results for the First Quarter Ended March 31, 2020. Retrieved July 27, 2020, from https://www.businesswire.com/ news/home/20200430005944/en/Public-Storage-Reports-Results-QuarterEnded-March

Business Wire. (2020b). Alphatec Holdings Terminates Tender Offer Agreement with EOS imaging. Retrieved July 27, 2020, from https:/www.businesswire.com/ news/home/20200426005051/en/Alphatec-Holdings-Terminates-Tender-OfferAgreement-EOS

CCSA (2020). How COVID-19 is changing the world: a statistical perspective. UN.

Clift, K., \& Court, A. (2020). How are companies responding to the coronavirus crisis?. Retrieved July 27, 2020, from https://www.weforum.org/agenda/2020/03/howare-companies-responding-to-the-coronavirus-crisis-d15bed6137

Check Point Software Technologies (2020). Coronavirus update: as economic stimulus payments start to flow, cyber-attackers want to get their share too. Retrieved July 24, 2020, from https://blog.checkpoint.com/2020/04/20/coronavirus-update-as-economicstimulus-payments-start-to-flow-cyber-attackers-want-to-get-their-share-too/

Company News HQ (2020). Asia Pacific Village Group to Terminate Scheme Implementation Agreement with Metlifecare. Retrieved July 27, 2020, from https://www.companynewshq.com/company-news/private-equity-companynews/asia-pacific-village-group-to-terminate-scheme-implementationagreement-with-metlifecare/

Deloitte (2020). Leadership in the crucible of crisis. Retrieved July 25, 2020, from https://www2.deloitte.com/si/en/pages/about-deloitte/articles/the-heart-ofresilient-leadership.html

Deloitte Insights. (2020). The heart of resilient leadership: Responding to COVID-19. DTTL.

George, M., \& Lukhele, N. (2020). 3 ways digital businesses can enable the Great Reset. Retrieved July 27, 2020, from https://www.weforum.org/covid-action-platform/ articles/3-ways-digital-business-can-enable-the-great-reset 
Ggrasia. (2020). Crown Resorts inquiry halted due to Covid-19 pandemic. Retrieved July 27, 2020, from https://www.ggrasia.com/crown-resorts-inquiry-halted-dueto-covid-19-pandemic/

Isenberg, D., Onyemah, V., Eisenman, E., \& Mulcahy, K. (2020). 5 ways entrepreneurs and SMEs can build resilience in a coronavirus economy. Retrieved July 27, 2020, from https://www.weforum.org/agenda/2020/05/entrepreneurs-smes-resiliencecoronavirus-economy/

ITC (2020). SME Competitiveness Outlook 2020: COVID-19: The Great Lockdown and its Impact on Small Business. Geneva. p. 38.

Janjić, V., Bogićević, J., \& Krstić, B. (2019). Kaizen as a global business philosophy for continuous improvement of business performance. Ekonomika, 65(2), 13-25.

Kose, A., \& Sugawara, N. (2020). Understanding the depth of the 2020 global recession in 5 charts. Retrieved July 24, 2020, from https://blogs.worldbank.org/opendata/ understanding-depth-2020-global-recession-5-charts

Kostin, K. B. (2019). Investment appeal assessment of international corporations. Strategic Management, 24(1), 3-9.

Renjen, P. (2020). The heart of resilient leadership: Responding to COVID-19. Retrieved July 25, 2020, from: https://www2.deloitte.com/us/en/insights/ economy/covid-19/heart-of-resilient-leadership-responding-to-covid-19.html

Reuters (2020). Couche-Tard shelves \$5.6 billion Caltex Australia buyout as deal becomes latest virus victim. Retrieved July 25, 2020, from: https://www.reuters. com/article/us-caltex-australia-m-a-alim-couche-tard/couche-tard-shelves5-6-billion-caltex-australia-buyout-as-deal-becomes-latest-virus-victimidUSKBN2210XT

Stojadinović Jovanović, S. (2015). Savremeni trendovi u globalnim tokovima stranih direktnih investicija. Međunarodni problemi, 1(2015), 79-105.

UNCTAD (2020). World Investment Report 2020. New York and Geneva.

WB (2020). Global Economic Prospects June 2020. WB Group, Washington.

WB Open Data (2020). "Final consumption expenditure (annual \% growth) - World", Retrieved July 25, 2020, from: https://data.worldbank.org/indicator/NE.CON. TOTL.KD.ZG? end=2020\&start=1955\&view=chart

WEF (2020a). COVID-19 Risks Outlook: A Preliminary Mapping and Its Implications. Geneva.

WEF (2020b). The Global Risks Report 2020. Geneva.

WTO (2020). Trade falls steeply in first half of 2020. Press Release 22 June 2020. Retrieved July 24, 2020, from https://www.wto.org/english/news_e/pres20_e/ pr858_e.htm 